Niepodległość. Idee, fakty, perspektywy. W 100. rocznicę odzyskania niepodległości przez Polskę, red. P. Krokosz, S. Romański-Cebula, Kraków 20I9, s. 5I-67 DOI: http://dx.doi.org/IO.I5633/9788374388085.04

\title{
Bohdan Hulewicz i jego działalność niepodległościowa w Wielkopolsce
}

\begin{abstract}
Abstrakt
Artykuł opisuje działalność niepodległościową Bohdana Hulewicza w Wielkopolsce ze szczególnym uwzględnieniem jego roli w przygotowaniach do powstania wielkopolskiego w I9I8 roku oraz udziału w nim. Aktywność niepodległościową Hulewicza można zobrazować na podstawie jego wspomnień pt. Wielkie wczoraj w małym kręgu. Należał on do organizacji patriotycznej Towarzystwo Tomasza Zana oraz Związku Młodzieży Polskiej „Zet”. W czasie powstania wielkopolskiego pełnił funkcję szefa Wydziału Operacyjnego w sztabie Dowództwa Głównego Wojsk Powstańczych i sztabu 3 Dywizji Strzelców Wielkopolskich.
\end{abstract}

Stowa kluczowe

Bohdan Hulewicz, powstanie wielkopolskie, Wielkopolska, I9ı8/ı9ı9, Poznań, Towarzystwo Tomasza Zana

\section{Abstract}

Bohdan Hulewicz and his independence activity in Greater Poland.

Bohdan Hulewicz's independence activity in Greater Poland is presented in the article with particular reference to his part in preparations and participation in the Greater Poland uprising in I9I8. Hulewicz's independence activity can be pictured on the basis of his memoirs entitled Great yesterday in the small circle. He belonged to the patriotic organization of Tomasz Zan Association and "Zet". During the Greater Poland uprising he was Chief of Operating Department in the staff of the Main Command of Insurgent Armies and the staff of the 3 rd Division of Greater Poland Rifles. 
Keywords

Bohdan Hulewicz, the Greater Poland uprising, Greater Poland, I9I8/I9I9, Poznań, Tomasz Zan Association

Postać Bohdana Hulewicza nie została dotychczas szerzej przedstawiona w publikacjach naukowych. Jego nazwisko pojawia się w literaturze na temat powstania wielkopolskiego z uwagi na jego czynny udział w tym wydarzeniu. Więcej na temat Bohdana Hulewicza i jego kluczowej roli w Powstaniu Wielkopolskim napisał Stanisław Jerzy Stam w swoim tekście Wspomnienie na tle bohaterstwa i martyrologii trzech braci Hulewiczów ${ }^{\mathrm{T}}$. Jednak cennym materiałem umożliwiającym szczegółowe opisanie jego roli w powstaniu wielkopolskim są wspomnienia wydane na pięćdziesiątą rocznicę powstania pt. Wielkie wczoraj $w$ matym kręg ${ }^{2}$ oraz napisana przez niego publikacja Powstanie Wielkopolskie: przyczynek do dziejów przewrotu z listopada i grudnia 1918 roku3 opisująca przygotowanie do powstania oraz jego przebieg. W zbiorach Biblioteki Zakładu Narodowego im. Ossolińskich we Wrocławiu znajduje się rękopis Hulewicza na temat historycznego znaczenia wydarzenia, jakim było powstanie wielkopolskie . Również fragment wspomnień Hulewicza dotyczący zamachu na ratusz i tworzenia oddziałów Służb Straży i Bezpieczeństwa w Poznaniu ukazał się w publikacji Poznańskie wspominki z lat 1918-19395.

Bohdan Hulewicz urodził się w I888 roku w Kościankach koło Wrześni. Jeden z siedmiorga rodzeństwa, wśród których chłopcy otrzymali

I Biblioteka Raczyńskich w Poznaniu (dalej: BR), S. J. Stam, Wspomnienie na tle bohaterstwa i martyrologii trzech braci Hulewiczów, sygn. 2706, k. 26-42.

2 B. Hulewicz, Wielkie wczoraj w matym kregu, Warszawa Ig68.

3 B. Hulewicz, Powstanie Wielkopolskie: przyczynek do dziejów przewrotu z listopada i grudnia 1918 roku, Zamość I920.

4 Biblioteka Zakładu Narodowego im. Ossolińskich we Wrocławiu (dalej: BO), B. Hulewicz, Znaczenie historyczne powstania wielkopolskiego, sygn.I409I/ II, k. I-I8.

5 B. Hulewicz, U progu nowej epoki, w: Poznańskie wspominki z lat 1918-1939, red. T. Kraszewski, T. Świtała, Poznań i973, s. 39-55. 
imiona słowiańskie niemające odpowiednika w języku niemieckim. W ten sposób ojciec Bohdana nie chciał narazić synów na zniekształcenie ich polskich imion. Od najmłodszych lat Hulewicz wychowywał się w domu rodzinnym z tradycjami patriotycznymi, już jego dziadek pułkownik walczył w czasie Wiosny Ludów w bitwach o Miłosław i Wrześnię, a ojciec pełnił rolę jednego z głównych organizatorów strajku szkolnego dzieci wrzesińskich ${ }^{6}$. Do późniejszej działalności w tajnych organizacjach samokształceniowych bracia Hulewiczowie zostali przygotowani przez rodziców, bowiem jak wspomina sam Bohdan: „Rodzice moi bardzo dbali o naukę języka polskiego, historii, literatury i geografii ziem polskich. Wszystkie wakacje były poświęcone intensywnej nauce pod kierownictwem rodziców, toteż moi trzej bracia i ja byliśmy do tej roli stosunkowo dobrze przygotowani”.

Bohdan uczęszczał do sześcioklasowego gimnazjum w Trzemesznie. Wtedy, w I905 roku, do szkoły przyjechali dwaj delegaci z gimnazjum gnieźnieńskiego, członkowie Towarzystwa Tomasza Zana: Józef Kostrzewski i Kazimierz Łuczewski. Hulewicz opisuje wyróżnienie go ze strony kolegów z Gniezna: „Organizacja kółka i jego kierownika zostało mnie powierzone, mimo, że w tym czasie zdawałem egzamin tzw. „jednoroczny” po 6 klasach gimnazjalnych. Sprawy kółka były bowiem na pierwszym planie nawet przed normalnymi obowiązkami nauki szkolnej"8.

Po zdaniu egzaminu w trzemeszeńskim gimnazjum kontynuował naukę w gimnazjum w Lesznie. Tam również zainteresował się dalszą działalnością w Towarzystwie Tomasza Zana (TTZ). Został wtedy skierowany do ucznia Kazimierza Siczyńskiego i po rozmowie z nim wywnioskował, że towarzystwo to istnieje, ale tylko na papierze. Po uwadze na temat ożywienia działalności w organizacji Siczyński oddaje Hulewiczowi kierownictwo nad kołem, ostrzegając go, że w gimnazjum leszczyńskim niewiele zdziała z uwagi na małą ilość

6 BR, S. J. Stam, Wspomnienie na tle bohaterstwa..., dz. cyt., k. 26-27.

7 BR, B. Hulewicz, Tajne związki samoksztatceniowe na terenie Wielkopolski, a zwłaszcza TTZ w Trzemesznie i Lesznie, sygn. 2706, k. 29.

8 BR, B. Hulewicz, Tajne związki samokształceniowe..., dz. cyt., k. 29. 
Polaków w szkole9. Jednak Hulewicz postanowił od nowa stworzyć koło, a zakup książek i podręczników do nauki załatwiał przy pomocy swoich rodziców, którzy udawali, że nie domyślają się, na co zostały przeznaczone te pieniądze. Poświęcenie Hulewicza na rzecz towarzystwa przyniosło swoje efekty, ponieważ koło leszczyńskie zaliczono do jednego z najlepiej prosperujących. Do organizacji w gimnazjum leszczyńskim należał również brat Bohdana Witold. Niestety intensywna praca w TTZ zwróciła podejrzenie opiekuna klasy, co Hulewicz opisuje następująco:

Ja osobiście poświęcałem się pracy w TTZ ze szkodą dla normalnej nauki w gimnazjum. Mój profesor i opiekun klasy Artur Bonin musiał mieć jakieś dane o naszym kółku TTZ. Mimo że postępy moje w klasie tego nie uzasadniały, świadomie obniżył mi stopnie i nie zakwalifikował do promocji i wezwał ojca, uprzedzając go o tym, że nie złożył żadnej denuncjacji, natomiast poradził ojcu, żeby mnie natychmiast $\mathrm{z}$ gimnazjum odebrał ${ }^{\mathrm{r}}$.

Ojciec Bohdana, z uwagi na doświadczenie z jego starszym bratem Jerzym, który w czasie uczęszczania do gimnazjum w Trzemesznie należał do TTZ i został wyrzucony ze szkoły przed ukończeniem sześcioletniej edukacji, a później groziła mu trzyletnia służba wojskowa, w I909 roku odebrał syna z gimnazjum w Lesznie i oddał do szkoły na zachodzie w mieście Neuhaldensleben, niedaleko Magdeburga. Tam Bohdan zdał maturę z odznaczeniem, gdyż będąc tam jedynym Polakiem siłą rzeczy nie był zaangażowany w działania konspiracyjne ${ }^{\text {II }}$.

Po ukończeniu szkoły studiował filozofię i historię sztuki we Włoszech, Monachium i Kilonii. W I9I2 roku został członkiem Związku Młodzieży Polskiej „Zet”, a potem wybrano go instruktorem w Drużynach Strzeleckich w Monachium. W październiku zgłosił się do komisji poborowej, by zdobyć wyszkolenie wojskowe i uzyskać stopień podporucznika rezerwy, co stanowiło wymóg programowy „Zetu”. Hulewicz zdecydował się wybrać batalion morski stacjonujący w Ki-

9 BR, B. Hulewicz, Gimnazjum Komeniusza w Lesznie wl. 1906-1907, sygn. 2706, k. 3I.

Io BR, B. Hulewicz, Gimnazjum Komeniusza w Lesznie..., dz. cyt., k. 32.

I I A. Hulewicz-Feillowa, Rodem z Kościanek, Kraków I988, s. 49. 
lonii, gdzie uzyskał wyszkolenie w piechocie i marynarce wojennej w latach I9I2-I9I3. Doświadczenie wojskowe, jak opisał Hulewicz, miały mu potem przydać się do ćwiczeń i musztry w tajnej organizacji młodzieży: „Słuchałem pilnie, by doświadczenia wykorzystać, jako instruktor w Drużynach Strzeleckich i kiedyś skutecznie bić Niemców. Przydała mi się ta szkoła już niebawem, w igı8 roku w Poznaniu i w Poznańskiem” ${ }^{\text {I2 }}$ W czasie oblężenia Antwerpii został ranny, a po dziesięciotygodniowym leczeniu i dwutygodniowym urlopie powrócił na front we Flandrii. Na froncie przebywał przez jedenaście miesięcy, po czym skierowano go do Munsterlager na dwumiesięczny kurs oficerski dla podoficerów. Po awansie na podporucznika w I9ı6 roku ponownie znalazł się na froncie. Okres służby Hulewicza w Kilonii i jego udział w walkach I wojny światowej opisuje w swoich wspomnieniach Agnieszka Hulewicz-Feillowa, córka Witolda:

Młodszy, Bohdan, służąc w Kilonii, przechodził forsowne ćwiczenia mobilizacyjne, nocne alarmy i długodystansowe marsze. Następnie z armią niemiecką przeżył inwazję na Belgię, szarpiąc się wewnętrznie i nie wiedząc, jak się zachować. Walka po stronie wroga była wręcz paradoksalna dla tego urodzonego wojskowego i patrioty ${ }^{13}$.

Po raz drugi ranny został w marcu I9I6 roku w czasie szturmu na Antwerpię i dzięki znajomemu lekarzowi przewieziono go do szpitala w Poznaniu. Po powrocie na front walczył we Flandrii oraz w bitwie pod Sommą, gdzie został trafiony odłamkiem granatu w kolano i ponownie przetransportowany do szpitala w Poznaniu. Po rocznym pobycie w szpitalu dr Franciszek Pawlicki zakwalifikował go do służby garnizonowej. W I9I7 roku, chcąc uniknąć ponownego wysłania do garnizonu w Kilonii, postarał się o przeniesienie do Warszawy w roli tłumacza w niemieckim biurze wojskowym. W tym czasie wspólnie z braćmi Jerzym i Witoldem zorganizował Spółkę Wydawniczą „Ostoja” i pełnił funkcję jej pierwszego kierownika. W okresie pobytu w Warszawie został kurierem pomiędzy Poznaniem a Warszawą do Koła

\footnotetext{
I2 B. Hulewicz, Wielkie wczoraj..., dz. cyt., s. I7.

I3 A. Hulewicz-Feillowa, Rodem z Kościanek, dz. cyt., s. 78.
} 
Międzypartyjnego, przewożąc tajne instrukcje. Wspomina, że do tej roli przygotowywała go sama Zofia Sokolnicka: „Wszystkie odezwy nosiły charakter antyniemiecki, ale niczego pisemnego przy sobie nie miałem nigdy. Sokolnicka pilnowała mnie i egzaminowała mnie, czy potrafię powtórzyć w Warszawie to, czego miałem się nauczyć w Poznaniu”I4. W styczniu I9I8 roku ponownie skierowano go do jednostki w Kilonii. Pełnił tam funkcję adiutanta dywizji stoczniowej aż do wybuchu rewolucji w listopadzie i wtedy zdezerterował z wojska niemieckiego. Odbył długą podróż do Polski, najpierw pieszo do Lubeki, następnie pociągiem do Lipska. Stamtąd do Drezna, a dopiero później do Wrocławia. Celem ostatecznym podróży Hulewicza pozostał Poznań, do którego udało mu się przyjechać $\mathrm{z}$ Wrocławia.

Rolę, jaką odegrał w powstaniu, Bohdan Hulewicz przedstawił w swoich wspomnieniach Wielkie wczoraj w matym kręgu, tak ukazując swoją osobę: „Piszę o powstaniu wielkopolskim roku I9ı8/I9I9, o jego genezie na tle rewolucji i końca pierwszej wojny światowej, jako że byłem tych wydarzeń naocznym świadkiem, w przygotowaniu powstania reżyserem, a w samym powstaniu czynnym aktorem" ${ }^{\text {"s. }}$. Dlatego też w odniesieniu do rewolucji, jaka wybuchła w Niemczech, od razu po swym przyjeździe do Poznania postanowił działać. Udał się do biura „Ostoi” i spotkał tam swojego szkolnego kolegę Władysława Hedingera. Zadał mu pytanie, co się robi w Poznaniu wobec rychłej klęski Niemiec. Otrzymał od niego poradę, by udał się do działaczy politycznych, którzy gromadzą się w mieszkaniu dyrektora Towarzystwa Ubezpieczeń „Westa” Mariana Głowackiego. Po przybyciu do Głowackiego zastał tam członków Komitetu Obywatelskiego miasta Poznania przekształconego w Centralny Komitet Obywatelski. Hulewicz, dostrzegając, że na froncie było wielu dobrze wyszkolonych, którzy wkrótce wrócą do Poznania (takich też znaleźć można było w garnizonach w Poznańskiem), przedstawił pomysł utworzenia wojskowej siły zbrojnej. Jednak otrzymał informację od Wojciecha Korfantego, że istnieje już taka sekcja pod przewodnictwem porucz-

\footnotetext{
I4 B. Hulewicz, Wielkie wczoraj..., dz. cyt., s. 98.

I5 B. Hulewicz, Wielkie wczoraj..., dz. cyt., s. Io7.
} 
nika Bronisława Sikorskiego i z nim należałoby porozmawiać na ten temat. Tak to spotkanie z Sikorskim ocenia Hulewicz: „Niewiele się dowiedziałem na tym zebraniu, które zakończyło się ogólnym rozejściem na obiad. Niczego nie postanowiono, niczego nie uchwalono" ${ }^{\text {"16. }}$. Wracając, spotkał dawnego kolegę z czasów szkolnych Mieczysława Palucha. Zdał relacje z bieżących wydarzeń i w odpowiedzi na informację o wyjeździe Palucha powiedział: „Nie wyjeżdżaj, nie możesz wyjechać. Tu się będą dziać wielkie rzeczy”ㄱ. Oboje postanowili udać się do Bronisława Sikorskiego, aby porozmawiać o przygotowaniach do powstania. Hulewicz rzeczowo i stanowczo zadał pytanie o plan działania, o to, czy jest strategia na zajęcie punktów taktycznych w Poznaniu oraz o składnice broni i amunicji. W wyniku braku konkretnych odpowiedzi Sikorskiego postanowili skontaktować się z Wojciechem Korfantym na temat przedsięwzięć w tej sprawie. Korfanty przedstawił decyzję o powołaniu Rady Ludowej, a następnie Naczelnej Rady Ludowej, mającej sprawować władzę administracyjną. W wyniku rozmów i zapewnienia Hulewicza, że razem z Paluchem zajmą się wyszkoleniem i zorganizowaniem oddziałów polskich żołnierzy, Korfanty wydał zgodę na utworzenie sekcji wojskowej. Na zebraniu Centralnego Komitetu Obywatelskiego oficjalnie powołano Sekcję Wojskową, w skład której weszli: Mieczysław Paluch, Bronisław Sikorski i Bohdan Hulewicz ${ }^{18}$. Ustalono, że miała ona być w stałym kontakcie z powołanym Komisariatem Naczelnej Rady Ludowej.

Pierwszym zadaniem stojącym przed nowopowstałą sekcją wojskową było przejęcie władzy wykonawczej w Poznaniu, którą sprawowała Rada Robotników i Żołnierzy. Bohdan Hulewicz razem z Mieczysławem Paluchem podjęli decyzję o objęciu władzy poprzez zamach na posiedzeniu Rady Robotników i Żołnierzy, znanym w historii jako „zamach na ratusz”. Plan ten narodził się po rozmowie z Celestynem Rydlewskim i Adamem Piotrowskim o nastrojach panujących w nowo ukonstytuowanej Radzie Robotników i Żołnierzy (RRiŻ) oraz braku

I6 B. Hulewicz, Wielkie wczoraj..., dz. cyt., s. I I7.

I7 B. Hulewicz, Wielkie wczoraj..., dz. cyt., s. I I7.

I8 B. Hulewicz, Powstanie Wielkopolskie..., dz. cyt., s. I2. 
możliwości przyjęcia do swego grona tylu Polaków, ile obecnie zasiada w niej Niemców. Postanawiają wtargnąć na ich zebranie, wyznaczając termin I3 listopada o godzinie I7.00. Do tego zamachu zdecydowano zaangażować za pośrednictwem Wincentego Wierzejewskiego uzbrojonych chłopców z Polskiej Organizacji Wojskowej oraz oddział Stanisława Nogaja. Dokładnie zorganizowane działania zamachu ustaliły, że Hulewicz tego dnia miał od godziny i6.০o oczekiwać w pokoju „Westy” na „zamachowców”, a Paluch odpowiadał za udzielanie ścisłych instrukcji, jak mają zachować się bojówki zgromadzone na placu. Do harcerzy należało utrzymanie łączności między ratuszem a „Westą" '9. Tego dnia Hulewicz i Paluch razem z Mieczysławem Andrzejewskim i Henrykiem Śniegockim czekali na informację od Piotrowskiego czy RRiŻ zgromadziła się już w komplecie w Ratuszu. Po wtargnięciu na posiedzenie Hulewicz przedstawił swoje zdanie, że żołnierze poznańscy nie są reprezentowani w Radzie przez Polaków. Wspominał on, że gdy rozległy się oburzone krzyki Niemców, Paluch zniecierpliwiony gadaniną huknął w stół, mówiąc: „Dajecie Polakom - żołnierzom garnizonu te same prawa, co mają Niemcy, czy nie?”. W tym czasie pojawił się dym eksplodowanego granatu, przewodniczący August Twachtmann trząsł się i rzucił na szyję Hulewiczowi, mówiąc: „Panowie! Bracia! Kochani! Zgadzamy się na wszystko, czego chcecie. Nieporozumienie! Straszne nieporozumienie!”2。. Hulewicz ocenił, że „zamach” ten stał się pierwszym krokiem do stopniowego przejmowania władzy przez Polaków. Jak zauważył Zygmunt Wieliczka, na czoło działań obozu walki zbrojnej wysunęli się Mieczysław Paluch i Bohdan Hulewicz, którzy zostali skrytykowani za swoje zbyt odważne plany przez koła polityczne i zrozumieli, że stopień podporucznika armii niemieckiej nie był pozycją społeczną, z której można by realizować wielkie zamiary i w tym właśnie argumencie należałoby szukać źródła zamachu na ratusz ${ }^{2 \mathrm{r}}$. Zostali usunięci ze swoich urzędów m.in. dowódca twierdzy Poznań,

\footnotetext{
I9 B. Hulewicz, Wielkie wczoraj..., dz. cyt., s. I23.

20 B. Hulewicz, Wielkie wczoraj..., dz. cyt., s. I25.

2 I Z. Wieliczka, Wielkopolska a Prusy w dobie powstania 1918/1919, Poznań I932, s. I6.
} 
prezydent miasta Poznania, szef Komisji Kolonizacyjnej oraz prezydent policji. „Zamach na ratusz” w opinii zarówno samego Hulewicza, jak i niemieckiego działacza politycznego Georga Cleinowa uznawany jest za początek okresu przygotowawczego do powstania wielkopolskiego ${ }^{22}$. W wyniku przeprowadzonego zamachu usunięto czterech Niemców, a na ich miejsce wprowadzono czterech Polaków: Bohdana Hulewicza, Mieczysława Palucha, Henryka Śniegockiego i Zygmunta Wizę. W tym Hulewicz pełnił funkcję wiceprzewodniczącego Rady Żołnierzy, a Paluch został pełnomocnikiem Wydziału Wykonawczego przy dowództwie V Korpusu Armii. W ten sposób Polacy uzyskali kontrolę nad Komendą Miasta i dowództwem V Korpusu ${ }^{23}$.

Następnie w czasie posiedzenia Polskiego Sejmu Dzielnicowego obradującego 5 grudnia I9ı8 roku w Poznaniu dokonano wyboru składu Naczelnej Rady Ludowej, do której weszli jako zastępcy Bohdan Hulewicz i Mieczysław Paluch z Księstwa Poznańskiego ${ }^{24}$. Zabieg ten z ramienia Komisariatu Naczelnej Rady Ludowej miał na celu nawiązanie współpracy z reprezentantami walki zbrojnej w Poznańskiem, ale przez Palucha i Hulewicza odebrany został jako utrudnianie im pracy w organizowaniu oddziałów. Początkowo zostali oni wybrani członkami Naczelnej Rady Ludowej w roli reprezentantów i delegatów wojska polskiego, co nie spodobało się Wojciechowi Korfantemu, znającemu zapał obydwóch w dążeniu do zbrojnego rozstrzygnięcia sytuacji. Do pewnego poróżnienia między Hulewiczem i jego współpracownikami a Komisariatem Naczelnej Rady Ludowej doszło w sprawie przysięgi składanej przez utworzone oddziały. Przysięgano nie tak jak zwykle Narodowi Polskiemu, a w tym przypadku Komisariatowi Naczelnej Rady Ludowej. Stanowczość Hulewicza w tej kwestii stała się punktem kulminacyjnym, dając do zrozumienia Komisariatowi, że nie ma możliwości sprowadzenia go pod swoje rządy. Wybór Stanisława

\footnotetext{
22 BO, B. Hulewicz, Znaczenie historyczne..., dz. cyt., k. 7.

23 A. Czubiński, B. Miśkiewicz, Z. Grot, Powstanie Wielkopolskie 1918-1919. Zarys dziejów, Poznań I978, s. I I I

24 Dziennik Polskiego Sejmu Dzielnicowego w Poznaniu w grudniu 1918 r., Poznań I9I8, s. 92.
} 
Taczaka na naczelnego dowódcę powstania Hulewicz komentuje następująco: „Chęć pozbycia się nas była później głównym powodem decyzji mianowania kpt. Taczaka naczelnym wodzem, za którego kandydaturą przemawiał chyba najwięcej fakt, że jego rodzony brat był prałatem kapituły gnieźnieńskiej"25.

Teraz, jako członkowie Rady Robotników i Żołnierzy, Hulewicz wspólnie z Paluchem uważali formowanie polskich sił zbrojnych za najważniejsze zadanie. O możliwości zorganizowania oddziałów wojskowych Hulewicz wspomina, że taka okazja nadarzyła się po otrzymaniu z Berlina od dowództwa V Korpusu rozkazu ministerstwa obrony o tworzeniu oddziałów Służb Straży i Bezpieczeństwa. Kierowano się tym, by oddziały te przeciwstawiały się ewentualnym rozruchom w wyniku wybuchu rewolucji w Niemczech. Postanowiono, że obok Niemców przyjmowani będą również Polacy, co miało jedynie mieć charakter przejściowy, dopóki nie powrócą z frontu żołnierze niemieccy. Oddziały te miały pełnić służbę garnizonową, głównie wartowni$\mathrm{Cząq}^{26}$. W taki sposób Hulewicz opisał, jak można było to wykorzystać na korzyść Polaków: „Natychmiast zorientowaliśmy się, jaka to dla nas gratka. Po całonocnych naradach ułożyliśmy z Paluchem szczegółowy plan: ja załatwię sprawę z Wydziałem Wykonawczym Rady Robotników i Żołnierzy, Paluch uzgodni to z dowódcą V Korpusu. Apel o ochotniczej służbie wojskowej ogłosimy w gazetach i rozplakatujemy na ulicach" ${ }^{27}$. Odezwę tę napisał sam Bohdan Hulewicz, następnie wydano ją przez Wydział Wykonawczy Rady Robotniczej i Żołnierskiej. Jej fragment brzmiał następująco: „Żołnierze Polacy! Upadł rząd stary pod ciosami rewolucji. I my witamy nowy porządek, jako zaranie wolności. Do wolności zupełnej jednakże jeszcze daleka droga. Kto wiernym jest synem swej ojczyny, niechaj baczy, by ospałość, brak poświęcenia i swawoli nie splamiły naszych sztandarów”28. Należy

\footnotetext{
25 B. Hulewicz, Wielkie wczoraj..., dz. cyt., s. I 56.

26 J. Karwat, Od idei do czynu. Myśl i organizacje niepodległościowe w Poznańskiem w latach 1887-1919, Poznań 2002, s. 366.

27 B. Hulewicz, Wielkie wczoraj..., dz. cyt., s. I39.

28 B. Hulewicz, Powstanie wielkopolskie..., dz. cyt., s. 4I.
} 
zauważyć, że treść odezwy miała charakter polski i kierowano ją głównie do Polaków, a podpisali ją Hulewicz, będący wiceprzewodniczącym Wydziału Wykonawczego Rady Żołnierzy, wraz z przewodniczącym Augustem Twachtmannem. Przy przyjmowaniu ochotników stosowano pewien podstęp: rekrutowano Polaków z nazwiskiem o brzmieniu niemieckim albo nadawano fikcyjne nazwiska niemieckie. Tworzenie oddziałów Służby Straży i Bezpieczeństwa (SSiB) nie przebiegły do końca pomyślnie z uwagi na to, że oficerowie niemieccy z komendy miasta zorientowali się w tych zabiegach Polaków. Wobec tej sytuacji, gdy powołano pod broń pierwszych ochotników, zarząd garnizonu odmówił koszar. O tych utrudnieniach pisał również Hulewicz: „[...] intendentura wzbraniała się opłacać, ubierać i żywić ochotnika, powołując się na przepisy służbowe i wskazówki z Berlina. Trzeba było żelaznej energii naczelnika tych oddziałów Mieczysława Palucha oraz ofiarnej i wytężonej pracy jego współpracowników, aby postawić na swoim”29. Później Hulewicz postanowił, jako przewodniczący RRiŻ, wydać zakaz noszenia broni palnej bez zezwolenia, dlatego oddziałom niemieckim wracającym $\mathrm{z}$ frontu ją odbierano, a pozwolenie wydawano wyłącznie polskim żołnierzom. Krótko przed wybuchem powstania wielkopolskiego Hulewicz i Paluch mieli już utworzone oddziały polskich żołnierzy. Dookoła Poznania rozlokowane były pierścieniem oddziały, przeważnie kompanie z silnym oddziałem karabinów maszynowych m.in. w Gnieźnie, Wrześni, Środzie, Śremie, Kościanie, Buku, Szamotułach, Obornikach, Rogoźnie i Wągrowcu ${ }^{3 \circ}$. Najsilniejsze oddziały powstały w Ostrowie, Szczypiornie, Pleszewie i Jarocinie, a mniejsze w Trzemesznie, Kruszwicy, Inowrocławiu, Nakle, Kcyni, Czarnkowie, Pniewach, Grodzisku, Wielichowie, Poniecu oraz Miejskiej Górce. Oficjalnie były to plutony bezpieczeństwa Straży Ludowej, a w rzeczywistości zakonspirowane oddziały powstańcze. Paluch skupił się na terenie Poznania, a Hulewicz koordynował działania organizacyjno-wojskowe na terenie całego terytorium Poznańskiego. Obaj zostali członkami Wydziału Bezpieczeństwa Naczelnej Rady

29 B. Hulewicz, Powstanie wielkopolskie..., dz. cyt., s. I6-I7.

30 B. Hulewicz, Wielkie wczoraj..., dz. cyt., s. I57. 
Ludowej, zaś wokół nich skupiali się inni młodzi oficerowie i podoficerowie. Oficerowie ci nazwani zostali „Tajnym Sztabem Wojskowym”. Udało się stworzyć dowództwo dla zorganizowanych oddziałów. Grupa ta z uwagi na głównego organizatora nazywana była również „Grupą Palucha”. Podlegały jej powstające oddziały SSiB. Warto zaznaczyć, że Hulewicz już pod koniec grudnia pełnił funkcję w ukształtowanej strukturze organizacyjnej tej grupy jako zastępca dowódcy ${ }^{31}$. Hulewicz nawiązał poprzez swojego brata Jerzego kontakt ze Sztabem Generalnym Wojska Polskiego w Warszawie. Wtedy rodzinny majątek Hulewicza Kościanki koło Wrześni służył jako punkt meldunkowy z Warszawą, a role kurierów pełnili Bohdan i Jerzy Hulewiczowie, Mieczysław Paluch oraz Wincenty Wierzejewski ${ }^{2}$.

27 grudnia I9ı8 roku wybuchło w Poznaniu powstanie wielkopolskie. Chociaż przygotowania nie były ukończone, w wyniku walk prowadzonych pierwszego wieczora, w nocy i następnego dnia 28 grudnia, opanowano całe miasto z wyjątkiem kilku obiektów, m.in. cytadeli i części koszar. W swoich wspomnieniach Hulewicz pisał:

Przyspieszenie wybuchu powstania o kilkanaście dni bynajmniej nie świadczy o jego przypadkowości, bo sprowokowanie walk przez 6 pułk grenadierów pruskich w dniu 27 grudnia nie zastało nas nieprzygotowanych. Przygotowanie było dobre, chociaż nieukończone. Liczyliśmy się z terminem I5 stycznia I9I9 r., brak tych dwudziestu dni utrudnił nam zadanie, ale nie oznaczał katastrofy ${ }^{33}$.

Z pomocą do stolicy Wielkopolski przybyła kompania piechoty z Pleszewa wezwana przez Mieczysława Palucha, a także kompania kórnicka oraz wrzesińska. Po objęciu dowództwa nad powstaniem wielkopolskim przez gen. Józefa Dowbora-Muśnickiego, Hulewicz sprawował funkcję szefa oddziału I organizacyjnego, a następnie szefa sztabu 3 Dywizji Strzelców Wielkopolskich, noszącej później nazwę I7 Dywizji Poznańskiej. Tam współpracował z nim Feliks Sobczyński, wywodzący się tak samo jak jego szef z ruchu niepodległościowego,

\footnotetext{
3 I J. Karwat, Od idei do czynu..., dz. cyt., s. 387.

32 J. Karwat, Od idei do czynu..., dz. cyt., s. 397.

33 B. Hulewicz, Wielkie wczoraj..., dz. cyt., s. I64.
} 
zakonspirowanego w Towarzystwie Tomasza Zana w Rogoźnie. Mówiąc o swoich najbliższych współpracownikach, Hulewicz podkreślał, że byli to w pierwszej linii oficerowie i podoficerowie, którzy opuścili szeregi armii niemieckiej, którzy byli: „od najwcześniejszej młodości zaprawieni w konspiracyjnej robocie i walce o niepodległość Polski, czy to w strajkach szkolnych, czy w kołach gimnazjalnych T. T. Z. czy w grupach Narodowych i „Zecie” na uniwersytetach w Niemczech, czy wreszcie w harcerstwie, Drużynach Strzeleckich"34.

Jerzy Stam w swoich wspomnieniach napisał, że Hulewicz udział w powstaniu wielkopolskim określał „wiosną swego życia”, co potwierdza ogrom entuzjazmu i zaangażowania, jaki włożył w to przedsięwzięcie.

Działalność niepodległościowa Hulewicza nie zakończyła się z chwilą wygrania powstania wielkopolskiego. Wchodził on w skład delegacji Naczelnej Rady Ludowej, uczestniczącej w otwarciu obrad Sejmu Ustawodawczego w Warszawie ıo lutego ı9ı9 roku35. W okresie międzywojennym ukończył Wyższą Szkołę Wojskową, później pracował w Wydziale Operacyjnym Sztabu Głównego. W latach I924-I926 pełnił funkcję attaché wojskowego w Madrycie oraz Waszyngtonie w stopniu podpułkownika, objął dowództwo 64 Pułku w Grudziądzu, a następnie został komendantem Szkoły Podchorążych Piechoty w Ostrowi Mazowieckiej. Powierzono mu dowództwo 26 Dywizji Piechoty w Skierniewicach ${ }^{36}$. W I938 roku otrzymał przydział na stanowisko dowódcy Obozu Warownego Grodno. W chwili wybuchu II wojny światowej Hulewicz wykazał się zmysłem organizacyjnym znanym z czasów Powstania Wielkopolskiego i z własnej inicjatywy uformował dywizję rezerwową Grodno pomimo braku pozwolenia od Naczelnego Dowództwa. Został jej dowódcą i walczył z powodzeniem na przedpolach Grodna. I7 września przedostał się do Rumunii, gdzie został internowany. W I94I roku aresztowano go i przebywał

34 BR, S. J. Stam, Wspomnienie na tle bohaterstwa..., dz. cyt., k. 35.

35 Cz. Demel, Uzupetniajace wybory do sejmu w Wielkopolsce 1 czerwca 1919 r., "Studia i materiały do dziejów Wielkopolski i Pomorza” I2 (I976), s. I 57.

36 Wielkopolski Stownik Biograficzny, red. J. Topolski, Poznań I98ı, s. 26I. 
w oflagach w Dorsten i Dössel ${ }^{37}$. W niewoli niemieckiej, w Oflagu VIB w Dössel postawiono go przed hitlerowski sąd wojenny za kierownictwo w powstaniu wielkopolskim oraz za harde stanowisko wobec niemieckich władz obozowych, którym nie oddawał honorów wojskowych ${ }^{3}$. Oskarżono go o rzekome fałszerstwo akt personalnych, gdyż podawał się za Józefa Hulewicza. Było jasne, że w razie wyroku zostanie zdegradowany, wysłany do Buchenwaldu i tam zlikwidowany. Proces miał stwierdzić, że „Józef Hulewicz”, to w rzeczywistości Bohdan Hulewicz, jeden z czołowych przywódców powstania wielkopolskiego39. Dzięki świetnej znajomości języka niemieckiego udało się Hulewiczowi zdemaskować koronnego świadka oskarżenia. Wobec niemożności stwierdzenia przez władze obozowe i gestapo identyczności pułkownika Józefa Hulewicza, za jakiego się podał, z podporucznikiem Bohdanem Hulewiczem z I9ı8 roku został przez sąd wojenny zwolniony.

Po ciężkiej chorobie na szkorbut wskutek awitaminozy i po dłuższym pobycie w szpitalu amerykańskim oraz francuskim Hulewicz wrócił w I948 roku do Polski, następnie pracował na stanowisku planisty w Wojewódzkiej Komisji Planowania Gospodarczego w Gdańsku

Hulewicz otrzymał wiele odznaczeń wojskowych za swoją działalność niepodległościową, głównie za udział w powstaniu wielkopolskim. Były to m.in. Virtuti Militari w I92I roku, Krzyż Niepodległości z Mieczami w roku I929, Polonia Restituta Oficerski Krzyż w I932 roku, Złoty Krzyż Zasługi w I932 roku, Wielkopolski Krzyż Powstańczy otrzymany w I948 roku, Oficerska Legia Honorowa francuska, odznaczenie Komandora Orderu Gwiazdy w Rumunii oraz Złoty Krzyż Amerykański Crois of Honor ${ }^{4}$. Zmarł 3I lipca Ig 68 roku, niestety nie doczekując pięćdziesiątej rocznicy powstania wielkopolskiego. Na tą okazję wydano wspomnienia Bohdana Hulewicza Wielkie wczoraj w małym kręgu jako wyraz hołdu dla jego bohaterstwa i rozwagi.

\footnotetext{
37 Wielkopolanie XX wieku, red. A. Gulczyński, Poznań 200I, s. I73-I74.

38 BR, S. J .Stam, Wspomnienie na tle bohaterstwa..., dz. cyt., k. 36.

39 BR, S. J .Stam, Wspomnienie na tle bohaterstwa..., dz. cyt., k. 36.

40 BR, B. Hulewicz, Życiorys wtasny i biografie braci Jerzego i Witolda Hulewiczów, sygn. 2706, k. 24.

4I BR, B. Hulewicz, Życiorys wtasny i biografie..., dz. cyt., k. 25.
} 
Bohdan Hulewicz stanowi jedną z czołowych postaci powstania wielkopolskiego, bowiem to z jego inicjatywy zaczęto tworzyć struktury wojskowe. Za jego namową w Poznaniu pozostał Mieczysław Paluch, z którym wspólnie przejął władzę w Radzie Żołnierzy i Robotników. Hulewicz nie czekał na tworzenie administracji państwowej ani wojskowej. Sam postanowił dotrzeć do Centralnego Komitetu Obywatelskiego i nawiązać z nim kontakt. O powstaniu pisał, że

[...] było zrywem ludu wielkopolskiego bez różnicy klas społecznych, orientacji politycznych, pochodzenia, urodzenia, wieku, nawet płci; na przestrzeni I23-letniej niewoli zryw ten był czymś bezprzykładnym. To był nie tylko bunt i opór przeciwko wiekowemu okupantowi i jego polityce ujarzmienia ziem zabranych i wyniszczenia opornych patriotów polskich, lecz również przypomnienie całemu światu, że Wielkopolska jest i będzie ziemią polską²

Podkreślał wartość tego wydarzenia dla Wielkopolski oraz Polski, zwracając uwagę na trudną sytuację okresu odzyskiwania niepodległości. Można by przypuszczać, że Hulewicz przerysowuje znaczenie powstania wielkopolskiego z uwagi na bezpośredni w nim udział, jednak by pokazać słuszność swoich poglądów, przytacza słowa niemieckiego publicysty Fritza Vossberga z jego publikacji o powstaniu wielkopolskim:

Zdarzenia w Poznaniu z listopada I9I8 r. zyskały znaczenie historyczno-światowe. Spowodowały one bezsprzecznie, że Ententa uległa przy ustaleniu warunków pokojowych niesłychanym roszczeniem Polaków, do całego Poznańskiego, Prus Wschodnich i Zachodnich oraz do Śląska, że wprzódy takich zamiarów nie było świadczą o tym choćby głosy poważnej prasy zagranicznej, a nawet prasy polskiej i Poznańskiego, Kongresówki w listopadzie i grudniu I9I8 r.43.

Wspomnienia Bohdana Hulewicza oraz jego praca na temat genezy powstania wielkopolskiego zdaniem historyków zajmujących się tą tematyką pozostaje wciąż niezwykle przydatna dla celów badawczych, co podkreślają prace m.in. Janusza Karwata, Zdzisława Grota oraz Antoniego Czubińskiego 44 .

42 B. Hulewicz, Wielkie wczoraj..., dz. cyt., s. I66.

43 BO, B. Hulewicz, Znaczenie historyczne..., k. I7.

44 A. Czubiński, B. Miśkiewicz. Z. Grot, dz. cyt., s. Io; J. Karwat, dz. cyt., s. Io. 


\section{BI BLIOGRAFIA}

I. ŹRÓDモA

66

\section{I.I. ŹRÓDŁA ARCHIWALNE}

Biblioteka Raczyńskich w Poznaniu, B. Hulewicz, Gimnazjum Komeniusza w latach 1906-1909, sygn. 2706.

Biblioteka Raczyńskich w Poznaniu, B. Hulewicz, Życiorys własny i biografie braci Jerzego i Witolda Hulewiczów, sygn. 2706.

Biblioteka Raczyńskich w Poznaniu, S. J. Stam, Wspomnienie na tle bohaterstwa i martyrologii trzech braci Hulewiczów, sygn. 2706.

Biblioteka Raczyńskich w Poznaniu, B. Hulewicz, Tajne związki samoksztatceniowe na terenie Wielkopolski a zwłaszcza TTZ $w$ Trzemesznie i Lesznie, sygn. 2642 .

Biblioteka Zakładu Narodowego im. Ossolińskich we Wrocławiu B. Hulewicz, Znaczenie historyczne powstania wielkopolskiego, sygn. I409I/II.

\section{I.2. ŹRÓDŁA DRUKOWANE}

Dziennik Polskiego Sejmu Dzielnicowego w Poznaniu w grudniu 1918 r., Poznań igı.

Hulewicz, B., Powstanie Wielkopolskie: przyczynek do dziejów przewrotu z listopada i grudnia 1918 roku, Zamość I920.

Hulewicz, B., U progu nowej epoki, w: Poznańskie wspominki z lat 1918-1939, red. T. Kraszewski, T. Świtała, Poznań I973, s. 39-55.

Hulewicz, B., Wielkie wczoraj w matym kręgu, Warszawa I968.

Hulewicz-Feillowa, A., Rodem z Kościanek, Kraków I988.

2. OPRACOWANIA I ARTYKUŁY NAUKOWE

Czubiński, A., Miśkiewicz., B., Grot, Z., Powstanie Wielkopolskie 1918-1919. Zarys dziejów, Poznań i978. 
Demel, Cz., Uzupetniajace wybory do sejmu w Wielkopolsce 1 czerwca 1919 r., w: „Studia i materiały do dziejów Wielkopolski i Pomorza” I2 (I976), s. I53I9I.

Karwat, J., Od idei do czүnu. Myśl i organizacje niepodległościowe w Poznańskiem w latach 1887-1919, Poznań 2002.

Wielkopolanie XX wieku, red. A. Gulczyński, Poznań 200 I.

Wieliczka, Z., Wielkopolska a Prusy w dobie powstania 1918/1919, Poznań I932.

Wielkopolski Słownik Biograficzny, red. J. Topolski, Poznań ı98I. 


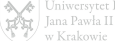

